\title{
Ecological analogies between estuarine bottom trawl fish assemblages from Patos Lagoon, Rio Grande do Sul, Brazil and York River, Virginia, USA
}

\author{
João P. Vieira \\ Departamento de Oceanografia, Universidade Federal do Rio Grande. Caixa Postal 474, 96201-900 Rio Grande, Rio Grande \\ do Sul, Brasil. E-mail: vieira@mikrus.com.br
}

ABSTRACT. The structure of estuarine fish assemblages at temperate latitudes in Patos Lagoon $\left(32^{\circ} 05^{\prime} \mathrm{S}, 52^{\circ} 04^{\prime} \mathrm{W}\right)$, Rio Grande do Sul, Brazil and York River ( $\left.37^{\circ} 17^{\prime} \mathrm{N}, 76^{\circ} 33^{\prime} \mathrm{W}\right)$, Virginia, USA was compared using mid and late 1970's data from bottom trawl collection to investigate whether geographically isolated fish assemblages have similar ecological structure given similar latitudinal positions on the warm-temperate southwestern and northwestern Atlantic regions, respectively. Since estuarine species often exhibit an ontogenetic shift in habitat requirements or preferences we examined Capture per Unity of Effort by size class (CPUE-SC) and split species into "size ecological taxa" (SET) for analysis. The use of CPUE-SC also allowed the abundance of a SET to be computed by summing the mean CPUE of each size class within that SET and use this information to follows SET's temporal and or spatial abundance. A total of 65 and 63 species was collected during a year of bottom trawling in the Patos Lagoon and York River estuaries, respectively. In both localities the strongest modal size class was $<80 \mathrm{~mm} \mathrm{TL}$, and several abundant species were smaller than $100 \mathrm{~mm}$ TL. The size between 80 and 100 TL effectively separated several species into discrete SET's in both systems. Those SET's could have different ecological preferences, temporal and spatial distributions and so identified as different "ecological taxa". In warm months, when predation by large fish is most likely, the abundance of fish between 80 and $100 \mathrm{~mm}$ TL in "bottom trawl" demersal fish assemblages was low in both systems. Only the sea catfishes, in Patos Lagoon, protected by strong dorsal and pectoral spines, and the Hogchoker, in the York River, protected by burrowing in the bottom substrate, peak in abundance at this size class. The seasonal pattern of estuarine use was similar between localities and did not differ from other warm-temperate estuarine fish assemblages.

KEY WORDS. Distribution; estuarine fishes; size; south-north comparison; zoogeography.

RESUMO. Analogias ecológicas entre as assembléias de peixes de fundo dos estuários da Laguna dos Patos, Rio Grande do Sul, Brasil e York River, Virginia, EUA. A estrutura das assembléias de peixes de dois estuários temperados - Lagoa dos Patos, Brasil e York River, Estados Unidos - foi comparada usando dados de rede de arrasto de fundo, da década de 70, em ambas as regiões. O objetivo do trabalho foi o de investigar se a fauna de peixes de dois estuários, localizados em duas regiões temperadas-quente do Atlântico, embora isolados geograficamente (Hemisfério Sul e Norte), apresentavam a mesma estrutura ecológica. Considerando a ontogenia das espécies utilizou-se o método da Captura por Unidade de Esforço por Classe de Tamanho (CPUE-CT) para separar as espécies dominantes em Unidades Ecológicas de Tamanho (UET). O uso da técnica do CPUE-CT permite que a abundância das UET seja computada através da soma da abundância de cada uma das classes de tamanho que incorporam estas UET e desta forma usar o CPUE das UET para estudar sua variação temporal ou espacial de abundância. Após um ano de coleta mensal foram observadas 65 espécies nas coletas de arrasto de fundo na Laguna dos Patos e 63 espécies no York River. Em ambas as localidades as maiores modas de tamanho foram menores que $80 \mathrm{~mm}$ de comprimento total (CT), e diversas espécies ocorrem em tamanho menor do que $100 \mathrm{~mm} \mathrm{CT}$. Entre 80 e $100 \mathrm{~mm}$ CT foi possível separar efetivamente diversas espécies em UET. Diferentes UET de uma mesma espécie ocorrem em diferentes habitats e em épocas distintas, podendo assim ser classificadas como "Taxas Ecológicos" distintos de uma mesma espécie. Nos meses quentes, quando ocorre a maior pressão de predação dos grandes peixes piscívoros, a abundância dos peixes com tamanhos entre 80 e $100 \mathrm{~mm}$ CT nas coletas de arrasto de fundo é baixa em ambos os sistemas. Somente dois grupos de peixes são abundantes neste tamanho, os bagres marinhos da Laguna dos Patos que estão protegidos da predação pelos espinhos dorsais e peitorais, e o linguado-Zebra no York River, que se enterra no substrato evitando a predação.

PALAVRAS CHAVE. Comparação sul-norte; distribuição; peixes estuarinos; tamanho; zoogografia. 
What processes determine biological community structure, the number, relative abundance and size distribution of species? Precise descriptions of ecological patterns are fundamental to create hypotheses about both the patterns and the mechanisms generating them (PETRIK \& LeVIN 2000). One way of testing hypotheses about the roles of different processes is to search for patterns, i.e. similarities or differences between the structures of specific communities occurring at geographically separate areas with similar climatic regimes (HARveY et al. 1983). Although the comparability of historical datasets is limited by differences in sampling regimes and methodologies (STOKEsbury et al. 1999, MATHiEson et al. 2000), comparative ecology can generate hypotheses, test existing theory, and draw attention to unique features of each entity under comparison (FeINSINGER 1990). Furthermore, comparisons between faunas of distinct regions are necessary to increase our understanding of several ecosystems. But comparisons between geographically distant systems are never perfectly controlled experiments. As closely as two sites can be matched, one can always find some environmental differences between them by going into fine detail (Westoby 1988, Mathieson et al. 2000).

Although the isotherms of $18-20^{\circ} \mathrm{C}$ may not represent precise boundaries between warm-temperate and tropical faunas, they approximate the average conditions where changes in estuarine fish species compositions generally occur. In this sense, the Patos Lagoon $\left(32^{\circ} \mathrm{S}\right)$ and the York River $\left(37^{\circ} \mathrm{N}\right)$, belong to two geographically distant but similar zoogeographic regions: the warm-temperate southwestern Atlantic and warm-temperate northwestern Atlantic regions, respectively (Ekman 1953, Vieira \& Musick 1994, Murdy et al. 1997, Aráujo \& Azevedo 2001).

Any expectation of similarities between estuarine bottom trawl fish assemblages in such attributes as numbers of species, individual size distribution, or species organization relies on the assumption that the sampling gear used collect similar fish assemblage (STOKESBURy et al. 1999) and that estuarine fish communities respond in similar ways to limited arrays of similar adaptive zones in similar environmental complexes (VIEIRA \& Musick 1993). Consequently if ecological similarity exists between Patos Lagoon and the York River such similarities might better be called ecological analogies (BLONDEL 1991). Therefore the objective of this study was to determine whether geographically isolated estuarine fish assemblages have similar structural patterns given similar sampling gear, design and estuarine environmental conditions.

\section{METHODS}

Patos Lagoon estuary $\left(32^{\circ} 05^{\prime} \mathrm{S} ; 52^{\circ} 04^{\prime} \mathrm{W}\right)$, Brazil: The data we used was from the BELAP Project, Laboratório de Ictiologia - Fundação Universidade Federal do Rio Grande, Brazil (CHAO et al. 1982, 1985, Vieira \& CASTello 1997). The subset chosen consists of data collected during January to December 1979. The study area extended from the lagoon mouth northward to about $40 \mathrm{~km}$ inside the lagoon. Sampling was conducted monthly from the $15 \mathrm{~m}$ yacht $\mathrm{R} / \mathrm{V}$ Larus. In each month, a set of about 20 randomly selected stations were chosen, and when conditions permitted, bottom hauls were made using an $8 \mathrm{~m}$ (head rope) shrimp trawl (11 $\mathrm{m}$ ground rope, $2 \mathrm{~m}$ legs on each side, $1.3 \mathrm{~cm}$ bar mesh wings and body with a $0.5 \mathrm{~cm}$ bar mesh cod end liner, and a pair of weighted otter doors).

York River estuary $\left(37^{\circ} 17^{\prime} \mathrm{N} ; 7^{\circ} 33^{\prime} \mathrm{W}\right)$, Chesapeake Bay, USA: The data for this portion of the study was obtained from Illowsky \& COLVOCORESSES (1975). A subset of 12 months (May 1973 to April 1974) was used in our analyses. The study area extended from the mouth of the river, where it joins the Chesapeake Bay, northwestward $18 \mathrm{~km}$ up the river. Samples were taken monthly at approximately 40 random-selected stations. Bottom hauls were made using a $4.9 \mathrm{~m}$ (head rope) semi-balloon shrimp trawl (7 m ground rope, $1.9 \mathrm{~cm}$ bar mesh, $0.63 \mathrm{~cm}$ bar mesh cod end liner and a pair of weighted otter doors). Tows were made from either the R/V Restless, or the R/V Brooks, both $10 \mathrm{~m}$ wooden workboats.

Although the net used at the York River was slightly smaller than the one used in the Patos Lagoon, mesh sizes where similar and it was assumed that both nets completely sampled the bottom trawl fish association, so any difference in size selectivity between the two would be inconsequential.

In both studies, hydrographic data including temperature and salinity were collected from bottom waters at each station. Selected beach seine stations $(<1 \mathrm{~m}$ depth) also were sampled monthly in both areas. In this paper, data from beach seine samples will be used only to complement information on bottom trawl data and to further elucidate the movement patterns of fish assemblages.

Fish were identified to species, enumerated, and their total biomass determined. For large catches, after sorting to species, and according to the size of the catch, samples were divided into four to twenty sub-samples of equal weight. Two to teen randomly selected sub-samples were processed individually, and the total number of individuals was then estimated by extrapolating from the mean of the counted sub-samples (mean number of fishes per unit weight).

Lengths (total or fork length where applicable) for all individuals of each species were measured and recorded in each sample unless sub-sampling was required. Where sub-sampling was used, proportional length frequencies were based upon the sub-samples.

For the 10 most numerically abundant species in each data set (Patos Lagoon and York River), CPUE by size class per sample was obtained by multiplying the ratio of the total number of individuals caught to the total number of individuals measured by the number of individuals measured for each 10 mm size class (GARCIA et al. 2001). The monthly mean CPUE of each size class for each species was plotted and analyzed for each data set. Based on the shape of this size class distribution and an examination of the data matrices for size-specific dis- 
tribution patterns, one or two size groups per species were identified. At this stage, the upper and lower level of the size range of each species sub-group was adjusted. The first size sub-group (juveniles) consisted of post-larvae and young-of-the-year. The second consisted of sub-adults or adults. The size groups selected for each species using this procedure were identified as "ecological taxa" (Polis 1984, Gelwick 1990), or "Size Ecological Taxa" (SET). The CPUE of a SET was computed by summing the mean CPUE of each size class $(10 \mathrm{~mm})$ within that SET (WHITESIDE \& НАTCH 1997, Garcia et al. 2001).

Abundance data (CPUE) of each SET (10 dominant species) and remaining species were pre-screened for the presence of unusual catches whose reliability was uncertain. To further reduce the effects of contagion, the numerical abundance data (CPUE) of each of the entities were transformed $\left[\log _{10}(\mathrm{CPUE}+1)\right]$ before cluster analysis. The similarity coefficient used was the Canberra Metric. The clustering strategy used was flexible fusion with beta set at the conventional value of -0.25. Entities (SET or species) were eliminated from cluster analysis if they contributed less than $0.01 \%$ to the total abundance (CPUE) or if they occurred in fewer than three monthly samples.

\section{RESULTS}

\section{Patos Lagoon, Brazil}

A total of sixty five species and 91,916 individuals, were collected from 253 samples taken from January-December of 1979 (Tab. I). Ten species constituted about 94\% of the total catch in number. The remaining 55 species each represented less than $1 \%$ of the total catch and accounted for a low average number of individuals per sample (CPUE).

The 10 dominant species were: seven sciaenids: Micropogonias furnieri (Desmarest, 1823), Cynoscion guatucupa (Cuvier, 1830), Macrodon ancylodon (Bloch \& Schneider, 1801), Ctenosciaena gracilicirrhus (Metzelaar, 1919), Paralonchurus brasiliensis (Steindachner, 1875), Umbrina canosai Berg, 1895, and Menticirrhus americanus (Linnaeus, 1758); one Batrachoididae: Porichthys porosissimus (Cuvier, 1829); one Engraulididae: Anchoa marinii Hildebrand, 1943; and three ariids: Genidens spp. Both Netuma barba (Lacepède, 1803) synonyms Genidens barbus (Lacepède, 1803) and Netuma planifrons Higuchi, Reis \& Araújo, 1982 synonyms Genidens planifrons (Higuchi, Reis \& Araújo, 1982) were collected in these samples. Genidens planifrons was not recognized as a separate species at the time these data were collected. Therefore, Genidens spp will be used in this paper to refer to G. barbus and G. planifrons collectively. The third ariid Genidens genidens (Cuvier, 1829) was easier identified.

Fish species in the Patos Lagoon collections were represented mostly by post-larvae, young-of-the-year and sub-adults, most ranged in length between 10 and $250 \mathrm{~mm}$ (Fig. 1). Figure 2 to 4 shows the cumulative percentage of the 10 dominant species in each $10 \mathrm{~mm}$ size class. Individuals less than $60 \mathrm{~mm}$ were encountered in all dominant species but Genidens spp., and several sciaenids were almost often restricted to this size class (e.g.
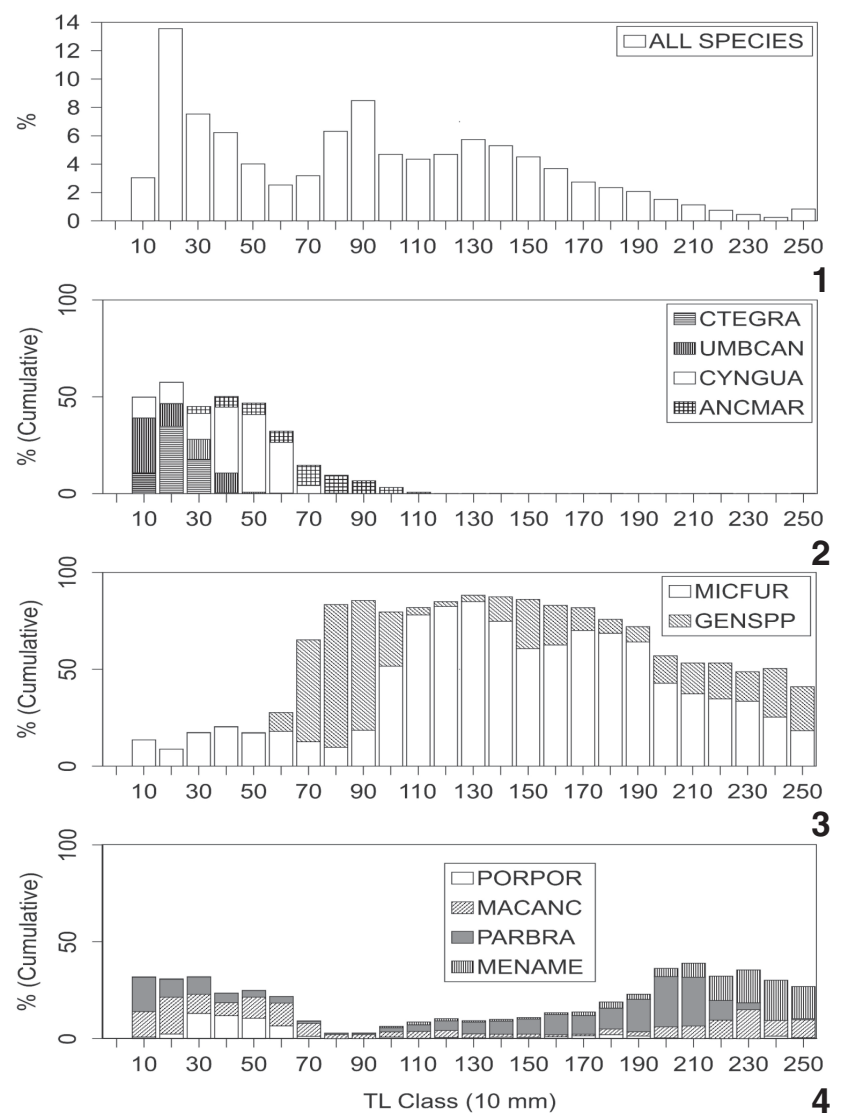

Figures 1-4. Percent (\%) size frequency distribution by $10 \mathrm{~mm}$ length class of all species caught at Patos Lagoon estuary (1). Cumulative percent contribution (\% cumulative) per size class $(10 \mathrm{~mm})$ of 10 dominant species (2-4). Note that each column of figures 2 to 4 add to almost $100 \%$, the remainder being attributable to non-dominant species. Species codes according to table I. January to December 1979.

Ctenosciaena gracilicirrhus, Umbrina canosai and Cynoscion guatucupa). The majority of individuals between 60 and $90 \mathrm{~mm}$ were Genidens spp. Individuals larger than $90 \mathrm{~mm}$ were mainly Micropogonias furnieri, other sciaenids (Paralonchurus brasiliensis, Macrodon ancylodon, Menticirrhus americanus), and Genidens spp. Micropogonias furnieri ranked first in number in bottom trawl samples and also was ranked among the four dominant species in beach seine samples (Tab. I, Fig. 5). This species occurred year-round in the Patos Lagoon estuary, with a size range of 10 to $\geq 250 \mathrm{~mm}$ (Fig. 5). The overall size frequency distribution suggested a bi-modal distribution. The first modal class (10-70 mm) occurred mainly from January to April in bottom trawl and beach seine samples but with peak abundance in May-June in beach seine samples. The second modal class $(\geq$ $80 \mathrm{~mm}$ ) occurred almost exclusively in bottom trawl samples year-round. Two SET's were selected (MICFUR-I and MICFURII) based upon the distinct temporal pattern of abundance and 


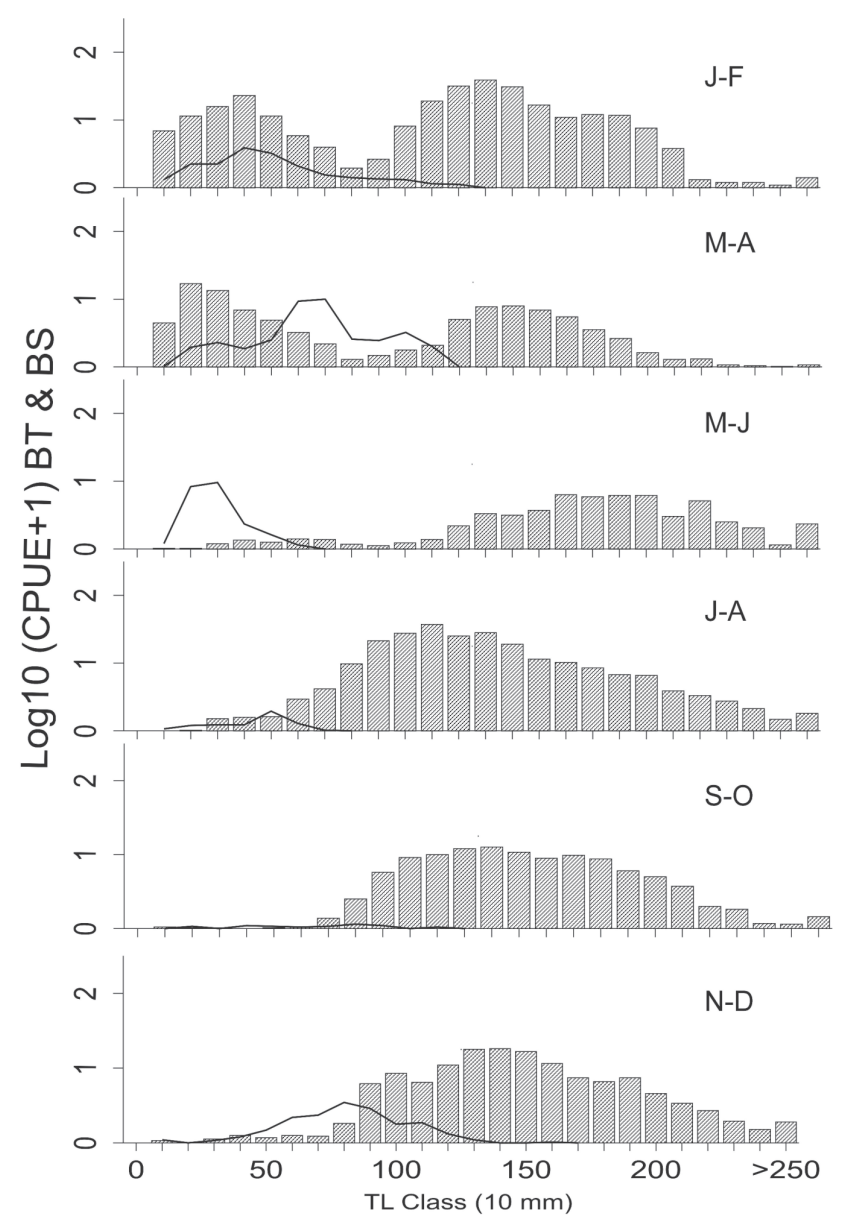

Figure 5. Bi-monthly CPUE by size class $(10 \mathrm{~mm})$ of Micropogonias furnieri caught at Patos Lagoon estuary. (BS) Beach seine samples (lines), (BT) bottom trawl samples (bars), January-February (J-F) to November-December (N-D) 1979.

occurrence of individuals smaller and larger than $80 \mathrm{~mm}$ (Fig. 6). This cutoff effectively separated the two cohorts during months both were taken in the bottom trawl samples (Fig. 5).

Sea catfish Genidens spp (size range $=50$ to $>250 \mathrm{~mm}$ ) ranked second in number in bottom trawl samples, and occurred year-round in the Patos Lagoon estuary (Tab. I, Fig. 6). Even though two size groups $(<120$, and $\geq 120 \mathrm{~mm})$ could be observed, subsequent cluster analyses revealed no temporal or spatial differences between these groups. The species was therefore treated as a single SET for subsequent cluster analysis.

Three sciaenids and Porichthys porosissimus were abundant and occurred year-round in the Patos Lagoon estuary with a size range of 10 to $\geq 250 \mathrm{~mm}$ (Tab. I, Fig. 6). Based upon the distinct temporal pattern of abundance and occurrence of individuals smaller and larger than $60 \mathrm{~mm}$ (M. americanus), $70 \mathrm{~mm}(P$. brasiliensis) and $80 \mathrm{~mm}$ (M. ancylodon and $P$. porosissimus), two
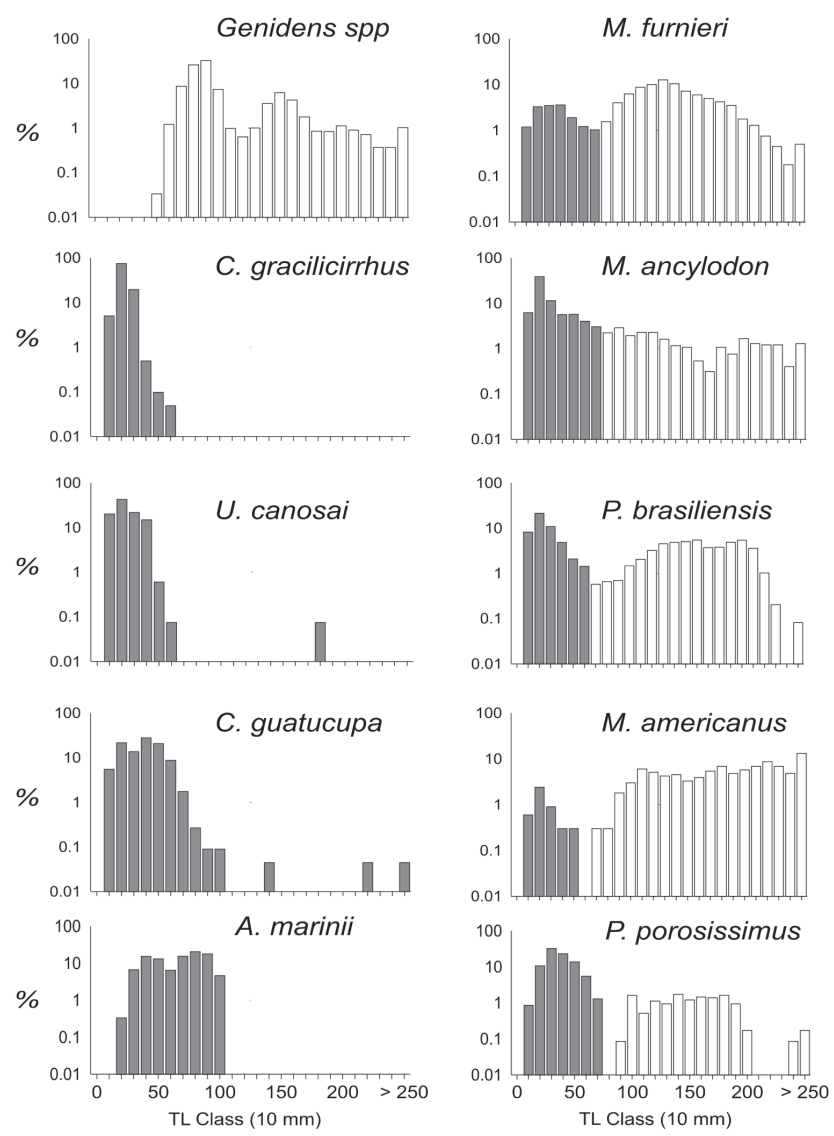

Figure 6. Percent size frequency distribution by $10 \mathrm{~mm}$ class length of 10 most abundant species at Patos Lagoon. Dark bars are Ecological Taxon I and open bars Ecological Taxon II. January to December of 1979 .

SET's for each species were selected. Only post-larvae and small juveniles $(<70 \mathrm{~mm})$ of Ctenosciaena gracilicirrhus were caught. This species occurred mostly from March to June, although it accounted for $6.6 \%$ by number of the total fishes captured between January and December of 1979 (Tab. I, Fig. 6). Post-larvae and small juvenile (<70 mm) Umbrina canosai represented $3.9 \%$ of the total catch of fishes (Tab. I). A few large individuals (180 $\mathrm{mm}$ size class) were caught in September, but are excluded from the subsequent analysis (Fig. 6).

Post-larvae and young-of-the-year of Cynoscion guatucupa ( $<110 \mathrm{~mm}$ ) occurred throughout the year, and its abundance peaked from July to October. This species was ranked third in number but sub-adults and adults were caught only occasionally in January and February. Individuals larger than $110 \mathrm{~mm}$ were infrequently collected and these were excluded from the analysis (Tab. I, Fig. 6). Anchoa marinii occurred year-round at a size range of 10 to $100 \mathrm{~mm}$, and this species was most abundant in winter. Two size modes $(<60$ and $\geq 60 \mathrm{~mm})$ could be 
Table I. More frequent and abundant species of fish caught in the Patos Lagoon estuary from January to December 1979 sorted by average CPUE (mean capture per unit of effort). Numerical abundance (ABUN), percent abundance (\%CPUE), and number of monthly frequency occurrence (FO).

\begin{tabular}{|c|c|c|c|c|c|c|}
\hline Species & Species cod & & $A B U N$ & CPUE & $\%$ CPUE & FO \\
\hline Micropogonias furnieri & MICFUR & $\#$ & 34524 & 134.58 & 38.94 & 12 \\
\hline Genidens spp. & GENSPP & $\#$ & 17176 & 59.88 & 17.32 & 12 \\
\hline Paralonchurus brasiliensis & PARBRA & \# & 6092 & 24.51 & 7.09 & 12 \\
\hline Cynoscion (striatus) guatucupa & CYNGUA & \# & 6604 & 22.41 & 6.48 & 10 \\
\hline Macrodon ancylodon & MACANC & $\#$ & 6184 & 22.37 & 6.47 & 12 \\
\hline Ctenosciaena gracilicirrhus & CTEGRA & $\#$ & 6094 & 20.32 & 5.88 & 3 \\
\hline Umbrina canosai & UMBCAN & \# & 3613 & 13.42 & 3.88 & 7 \\
\hline Anchoa marinii & ANCMAR & \# & 2449 & 12.05 & 3.49 & 11 \\
\hline Porichthys porosissimus & PORPOR & $\#$ & 2743 & 11.67 & 3.38 & 10 \\
\hline Menticirrhus americanus & MEMAME & $\#$ & 940 & 3.36 & 0.97 & 12 \\
\hline Peprilus paru & PEPPAR & $\#$ & 591 & 2.29 & 0.66 & 8 \\
\hline Lycengraulis grossidens & LYCGRO & \# & 531 & 2.11 & 0.61 & 12 \\
\hline Prionotus punctatus & PRIPUN & $\#$ & 528 & 1.99 & 0.58 & 11 \\
\hline Pogonias cromis & POGCRO & $\#$ & 554 & 1.74 & .50 & 8 \\
\hline Lagocephalus laevigatus & LAGLAE & $\#$ & 349 & 1.70 & 0.49 & 5 \\
\hline Syngnathus folleti & SYNFOL & $\#$ & 486 & 1.64 & 0.47 & 11 \\
\hline Achirus garmani & ACHGAR & $\#$ & 391 & 1.53 & 0.44 & 9 \\
\hline Trichiurus lepturus & TRILEP & $\#$ & 276 & 1.08 & 0.31 & 6 \\
\hline Engraulis anchoita & ENGANC & $\#$ & 247 & 1.08 & 0.31 & 3 \\
\hline Symphurus jenynsi & SYMJEN & $\#$ & 246 & 0.98 & 0.28 & 12 \\
\hline Selene setapinis & SELSET & \# & 189 & 0.74 & 0.21 & 5 \\
\hline Urophycis brasiliensis & UROBRA & $\#$ & 197 & 0.69 & 0.20 & 12 \\
\hline Trachinotus marginatus & TRAMAR & $\#$ & 128 & 0.46 & 0.13 & 7 \\
\hline Stellifer rastrifer & STERAS & $\#$ & 92 & 0.43 & 0.12 & 4 \\
\hline Pomatomus saltatrix & POMSAL & $\#$ & 78 & 0.29 & 0.08 & 7 \\
\hline Stromateus maculatus & STRMAC & $\#$ & 59 & 0.21 & 0.06 & 4 \\
\hline Genidens genidens & GENGEN & $\#$ & 59 & 0.21 & 0.06 & 8 \\
\hline Percophis brasiliensis & PERBRA & $\#$ & 61 & 0.20 & 0.06 & 6 \\
\hline Parapimelodus (valenciennesi) nigribarbis & PARNIG & $\#$ & 43 & 0.16 & 0.05 & 3 \\
\hline Menticirhus littoralis & MENLIT & \# & 35 & 0.13 & 0.04 & 7 \\
\hline Ramnogaster arcuata & RAMARC & $\#$ & 29 & 0.13 & 0.04 & 4 \\
\hline Pimelodus (clarias) maculatus & PIMMAC & \# & 26 & 0.11 & 0.03 & 3 \\
\hline Selene vomer & SELVOR & $\#$ & 26 & 0.10 & 0.03 & 3 \\
\hline Sympterygia bonaparte & SYMBON & \# & 24 & 0.08 & 0.02 & 6 \\
\hline Sympterygia acuta & SYMACU & $\#$ & 17 & 0.07 & 0.02 & 5 \\
\hline Paralichthys orbignyana & PARORB & $\#$ & 13 & 0.05 & 0.01 & 6 \\
\hline Chloroscombrus chysurus & CHLCRI & $\#$ & 13 & 0.05 & 0.01 & 3 \\
\hline Odontesthes bonariensis & ODOBON & $\#$ & 13 & 0.04 & 0.01 & 5 \\
\hline Mugil platanus & MUGPLA & & 10 & 0.04 & 0.01 & 2 \\
\hline Ophichthus gomesii & OPHGOM & \# & 10 & 0.04 & 0.01 & 6 \\
\hline
\end{tabular}

\# Denotes species used in cluster analysis.Total: 65 species; 91,916 individuals; 12 months; 253 samples. 
observed, but subsequent cluster analyses revealed no temporal or spatial differences between these groups. The species was therefore treated as a single SET for subsequent cluster analysis (Tab. I, Fig. 6).

Forty-three entities (10 SET's plus 33 species) were selected for cluster analysis (Tab. I). Pooled data on entities abundance by month resulted in cluster groups (Fig. 7) that could be characterized into the following seasonal groups: summer (January to March), fall (April and May), winter (June to August) and spring (September to December).

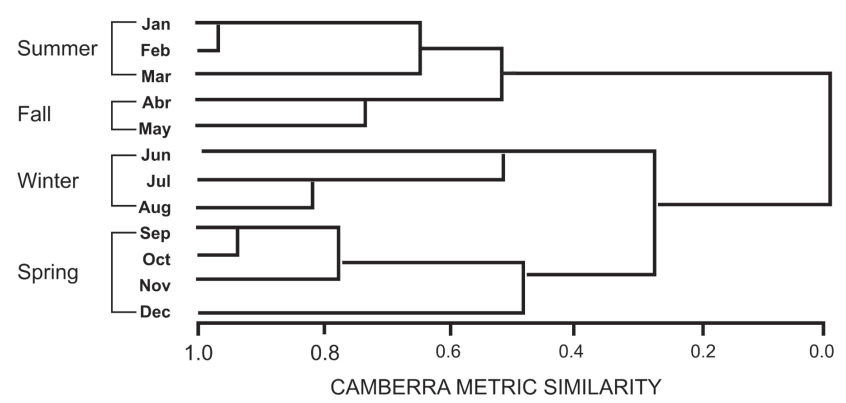

Figure 7. Dendogram of normal cluster analysis in the Patos Lagoon estuary.

Environmental data within these seasonal groups are summarized in figures 8 and 9 . Water temperature ranged between $19-25^{\circ} \mathrm{C}$ in the summer group and $10-16^{\circ} \mathrm{C}$ in winter. Wide temperature ranges were observed in all seasonal groups, but mean water temperature was considerably lower in winter $\left(12.5^{\circ} \mathrm{C}\right)$ than in the other seasons. Salinity ranged from 0 to 35 but was highly variable in summer, winter and spring. Summer and fall mean salinity was considerably higher than winter and spring.

Inverse cluster analysis identified 11 groups of entities, ranging in content from one to six entities per group (Tab. II). Groups A through E were characterized by presence throughout the year. Group J was missing in the summer, group F in summer and fall, group $\mathrm{K}$ in summer and spring, group I in winter, and Ctenosciaena gracilicirrhus (group H) together with group $\mathrm{G}$ in winter and spring.

\section{York River, Virginia, USA}

A total of sixty three species and 107.476 individuals, were collected from 495 samples taken from July 1973 to June 1974 (Tab. III). Ten species constituted about $99 \%$ of the total catch in number, while the remaining 53 species represented less than $0.1 \%$ of the total catch and a low average number of individuals per sample (CPUE < 0.2). Dominant species were: Anchoa mitchilli (Valenciennes, 1848) (Engraulididae), four species of Sciaenidae \{Leiostomus xanthurus, Lacepède, 1802, Micropogonias undulatus (Linnaeus, 1766), Cynoscion regalis (Bloch \& Schneider, 1801),
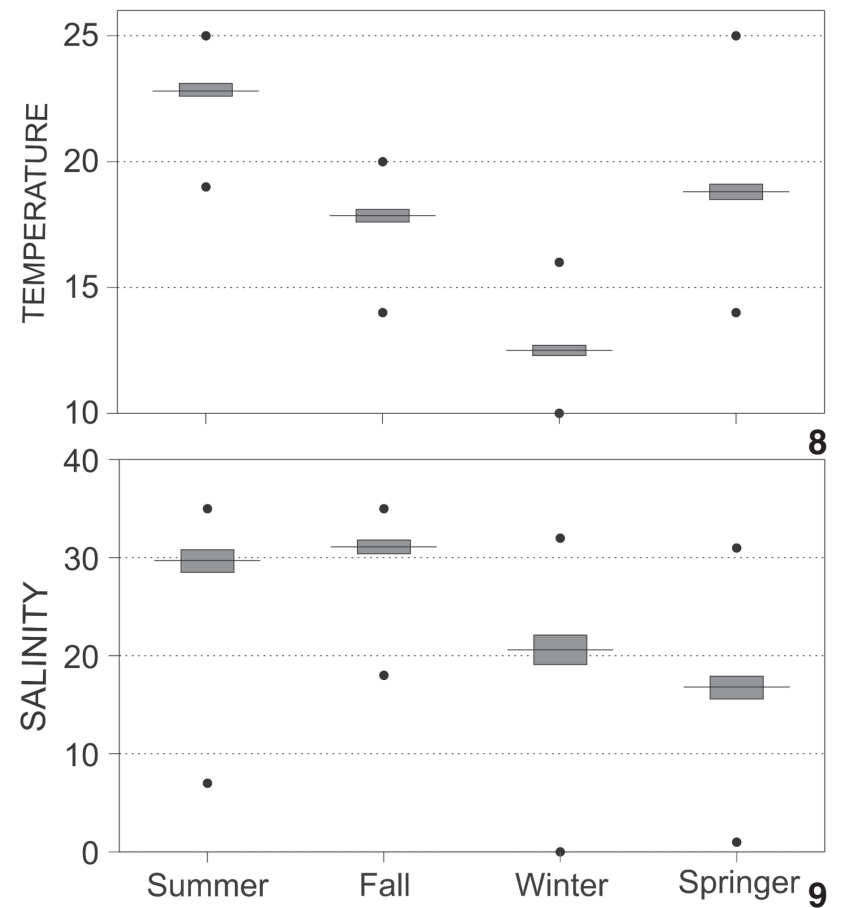

Figure 8-9. Salinity (8) and temperature (9) data within seasonal groups in the Patos Lagoon estuary. Mean (horizontal line), standard error of the mean (Box), and range (Dots).

and Bairdiella chrysoura (Lacepède, 1802)\}, Trinectes maculatus (Bloch \& Schneider, 1801) (Soleidae), Paralichthys dentatus (Linnaeus, 1766) (Bothidae), Opsanus tau (Linnaeus, 1766) (Batrachoididae), Urophycis regia (Walbaum, 1792) (Gadidae) and Menidia menidia (Linnaeus, 1766) (Atherinidae).

Fish species in bottom trawl collections from the York River were represented predominately by post-larvae, young-of-theyear, and sub-adults ranging in length between 10 and $250 \mathrm{~mm}$ or larger (Fig. 10). Anchoa mitchilli dominated the size classes between 10 and $60 \mathrm{~mm}$ of length (Fig. 10). Figure 11 shows the percent contribution of the three top remaining dominant species to the total number of individuals taken in each $10 \mathrm{~mm}$ size class (A. mitchilli was excluded). Individuals less than $70 \mathrm{~mm}$ were encountered in all dominant species, Micropogonias undulatus dominated this size range after $A$. mitchilli was removed. Leiostomus xanthurus showed a peak of dominance between 90 and $160 \mathrm{~mm}$, a size range that also encompassed most of the Trinectes maculatus captured. Individuals larger than $160 \mathrm{~mm}$ were well represented by all dominant species, except for $A$. mitchilli.

Leiostomus xanthurus ranked second in number in bottom trawl samples and also was ranked among the three dominant species in beach seine samples (Tab. III). This species occurred year-round in the York River, and most individuals were 90 to $150 \mathrm{~mm}$ (Fig. 12). Individuals less than $30 \mathrm{~mm}$ started 
Table II. Graphical characterization of CPUE variation of seasonal groups and species groups in the Patos Lagoon. Size range (mm).

\begin{tabular}{|c|c|c|c|c|c|c|}
\hline Groups & Species & Size Range & SUM & FAL & WIN & SPR \\
\hline \multirow[t]{6}{*}{ A } & Anchoa marinii & $10-100$ & +++ & +++ & +++++ & ++++ \\
\hline & Symphurus jenynsi & $30-230$ & ++++ & +++ & ++++ & +++ \\
\hline & Syngnathus folleti & $40-170$ & +++ & ++ & ++++ & +++ \\
\hline & Lycengraulis grossidens & $10-210$ & ++++ & +++++ & +++ & ++++ \\
\hline & Urophycis brasiliensis & $20->250$ & +++ & +++ & +++ & +++ \\
\hline & Pogonias cromis & $60->250$ & ++ & ++ & ++++ & ++++ \\
\hline \multirow[t]{4}{*}{ B } & Macrodon ancylodon I & $10-70$ & ++++ & ++++ & ++++ & +++ \\
\hline & Micropogonias furnieri I & $10-70$ & +++++ & ++++ & ++++ & +++ \\
\hline & Paralonchurus brasiliensis I & $10-60$ & +++++ & ++++ & ++++ & +++ \\
\hline & Prionotus punctatus & $10-60$ & ++++ & +++ & +++ & +++ \\
\hline \multirow[t]{6}{*}{$\mathrm{C}$} & Cynoscion guatucupa & $10-110$ & ++++ & +++ & +++++ & +++ \\
\hline & Genidens spp. & $50>250$ & ++++ & +++++ & ++++ & +++++ \\
\hline & Micropogonias furnieri II & $80>250$ & ++++ & ++++ & ++++ & +++++ \\
\hline & Paralonchurus brasiliensis II & $70>250$ & +++++ & ++++ & +++++ & ++++ \\
\hline & Macrodon ancylodon II & $80>250$ & ++++ & ++++ & ++++ & ++++ \\
\hline & Menticirrhus americanus II & $70>250$ & ++++ & ++++ & ++++ & ++++ \\
\hline \multirow[t]{4}{*}{$\mathrm{D}$} & Achirus garmani & $60-160$ & ++++ & +++ & +++ & ++++ \\
\hline & Genidens genidens & $60>250$ & +++ & +++ & ++ & +++ \\
\hline & Peprilus paru & $10-240$ & ++++ & ++++ & ++ & +++ \\
\hline & Porichthys porosissimus I & $10-70$ & +++++ & ++++ & ++ & ++ \\
\hline \multirow[t]{2}{*}{$\mathrm{E}$} & Paralichthys orbignyana & $120>250$ & ++ & ++ & ++ & ++ \\
\hline & Sympterygia bonaparte & $80>250$ & ++ & +++ & +++ & + \\
\hline \multirow[t]{3}{*}{$\mathrm{F}$} & Ramnogaster arcuata & $20-120$ & & & & +++ \\
\hline & Stromateus maculatus & $10-130$ & & & ++ & +++ \\
\hline & Pimelodus maculatus & $160>250$ & & & +++ & +++ \\
\hline \multirow[t]{5}{*}{ G } & Lagocephalus laevigatus & $30-140$ & ++++ & ++ & & \\
\hline & Selene setapinis & $30-100$ & +++ & ++++ & & \\
\hline & Stellifer rastrifer & $20-100$ & ++++ & ++ & & \\
\hline & Menticirrhus americanus I & $10-50$ & +++ & ++ & & \\
\hline & Selene vomer & $40-120$ & ++ & +++ & & \\
\hline $\mathrm{H}$ & Ctenosciaena gracilicirrhus & $10-60$ & +++++ & +++ & & \\
\hline \multirow[t]{6}{*}{1} & Porichthys porosissimus II & $90>250$ & ++++ & +++ & & +++ \\
\hline & Trachinotus marginatus & $50-180$ & +++ & ++++ & & +++ \\
\hline & Trichiurus lepturus & $30>250$ & ++++ & +++ & & ++ \\
\hline & Umbrina canosai & $10-60$ & +++ & +++ & & +++ \\
\hline & Menticirhus littoralis & $30>250$ & +++ & ++ & & +++ \\
\hline & Ophichthus gomesii & $220 \geq 250$ & ++ & ++ & & ++ \\
\hline \multirow[t]{4}{*}{ J } & Odontesthes bonariensis & $100-230$ & & ++ & ++ & +++ \\
\hline & Sympterygia acuta & $140 \geq 250$ & & ++ & +++ & ++ \\
\hline & Percophis brasiliensis & $170 \geq 250$ & & +++ & +++ & +++ \\
\hline & Pomatomus saltatrix & $90-250$ & & +++ & +++ & ++ \\
\hline \multirow[t]{2}{*}{$\mathrm{K}$} & Chloroscombrus chysurus & $30-110$ & & +++ & ++ & \\
\hline & Engraulis anchoita & $30-110$ & & ++++ & +++ & \\
\hline
\end{tabular}

Absent (empty), very low $(+<0.01)$, low $(++>0.01)$, moderate $(+++>0.1)$, high $(++++>1.0)$, very high $(+++++>10)$.

Revista Brasileira de Zoologia 23 (1): 234-247, março 2006 

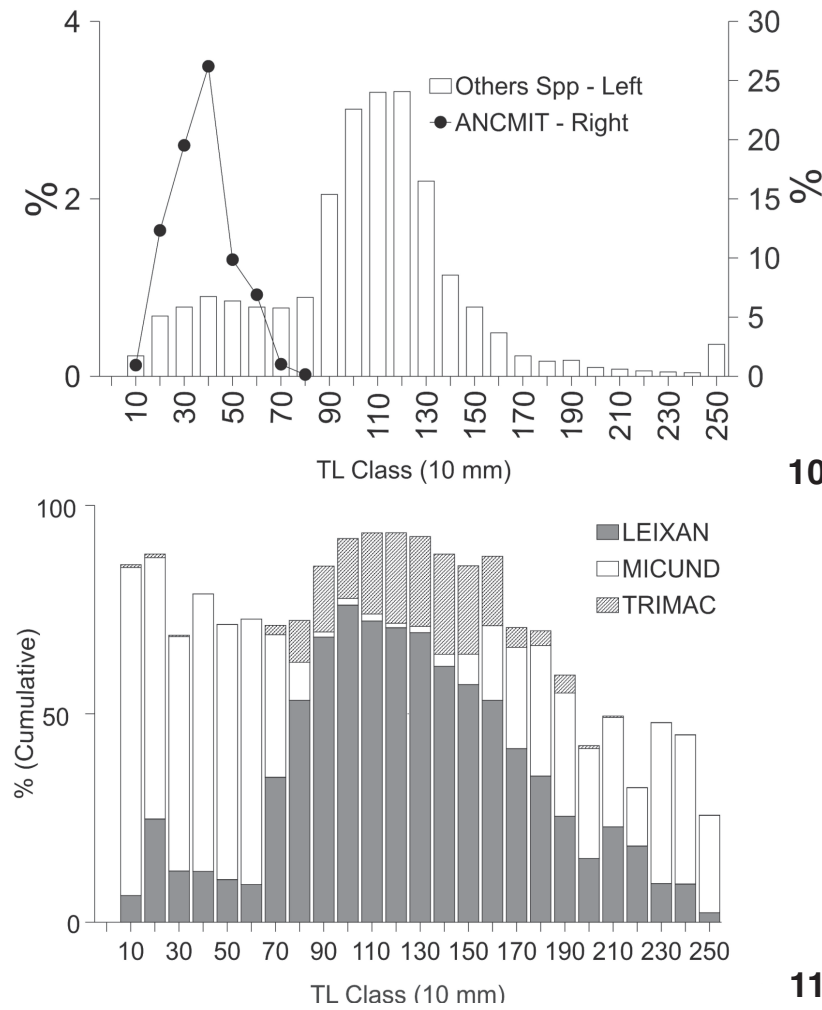

Figure 10-11. Percent size frequency distribution by $10 \mathrm{~mm}$ class length of Anchoa mitchilli (ANCMIT - line - right y-scale) and other species (Others spp. - bars - left y-scale) caught at York River estuary (10). Percent contribution per size class $(10 \mathrm{~mm})$ of the three dominant species after Anchoa mitchilli was excluded (11). Species codes according to table III. July 1973 to June 1974.

recruiting to the beach seine samples in March and to bottom trawl collections in April. Two annual cohorts were clearly evident in April, May and June, but they were not readily distinguishable from July to February as the older cohorts (1+) either because they became less susceptible to gears or left the area. Based upon the different temporal pattern of occurrence of those cohorts, two SET's were designated LEIXAN-I $(<80 \mathrm{~mm}$ length), and LEIXAN-II (> 80mm length). This cutoff effectively separated the two annual cohorts during months both were taken in the samples (Figs 12 and 13).

Anchoa mitchilli ranked first in number in bottom trawl samples and occurred year-round in the York River, with a size range of 10-80 mm (Tab. III, Fig. 13). Most individuals were 30$40 \mathrm{~mm}$. This species also ranked among the top five most abundant fishes in shallow water (beach seine samples) but was not caught in all months. Although the $40 \mathrm{~mm}$ cutoff level effectively separates small and rapidly growing new recruits from the larger, slower growing older individuals, subsequent cluster analyses revealed no temporal or spatial differences between

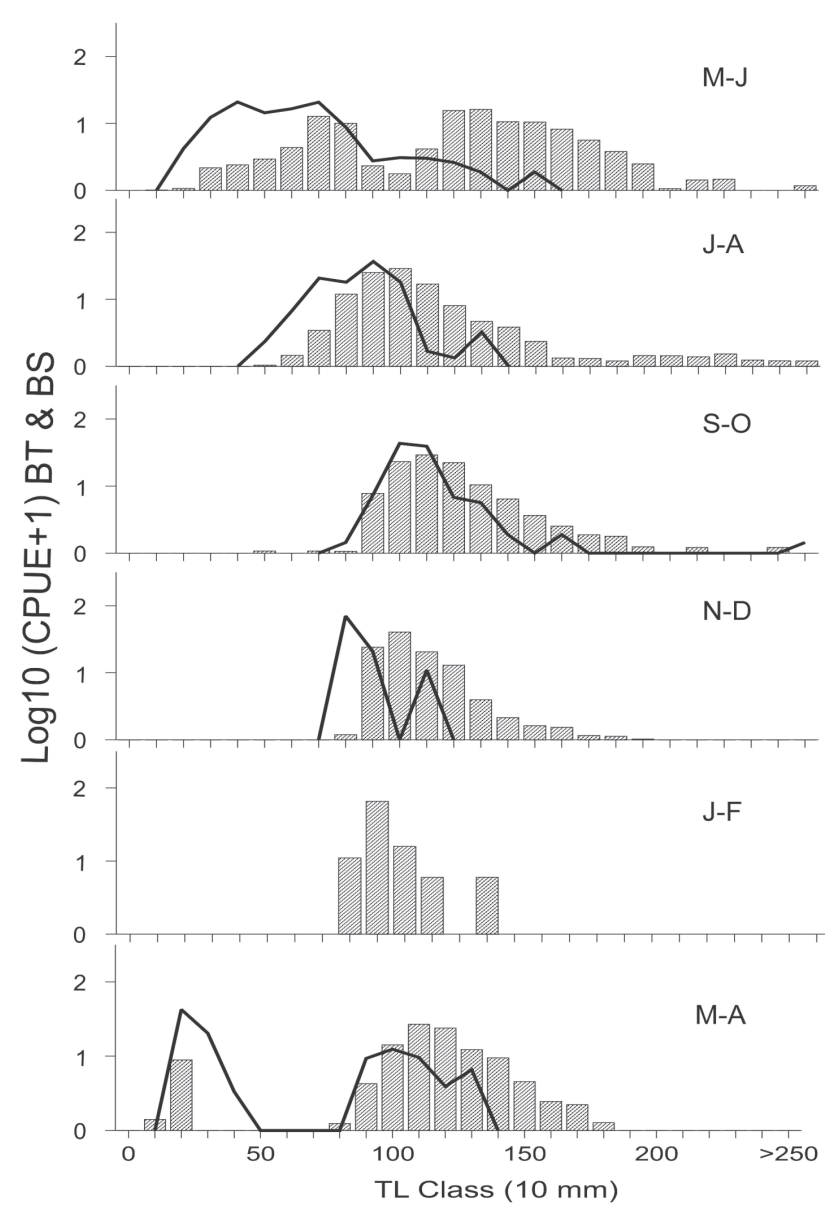

Figure 12 . Bi-monthly CPUE by size class $(10 \mathrm{~mm})$ of Leiostomus xanthurus caught at the York River estuary. BS = beach seine samples (lines), BT = bottom trawl samples (bars), May-June (M-J) 1973 to March-April (M-A) 1974.

those groups. The species was therefore treated as a single SET for subsequent cluster analysis.

Micropogonias undulatus ranked third in bottom trawl samples and occurred year-round (Tab. III, Fig. 13). The overall size frequency distribution suggested a bi-modal or tri-modal distribution. Cluster analysis suggested no major temporal differences in occurrence of individuals between 10-80 $\mathrm{mm}$ in length, and this size group was therefore treated as a single SET (MICUND-I). Based on the distinct temporal pattern of abundance of individuals larger than $80 \mathrm{~mm}$, a second SET category was selected (MICUND-II).

Trinectes maculatus ranked fourth in bottom trawl samples and occur year-round (Tab. III, Fig. 13). Overall and temporal size frequency distributions suggested a uni-modal distribution. Only very few individuals less than $70 \mathrm{~mm}$ were collected from July to December, therefore this species was treated as a single SET for future cluster analyses.

Revista Brasileira de Zoologia 23 (1): 234-247, março 2006 

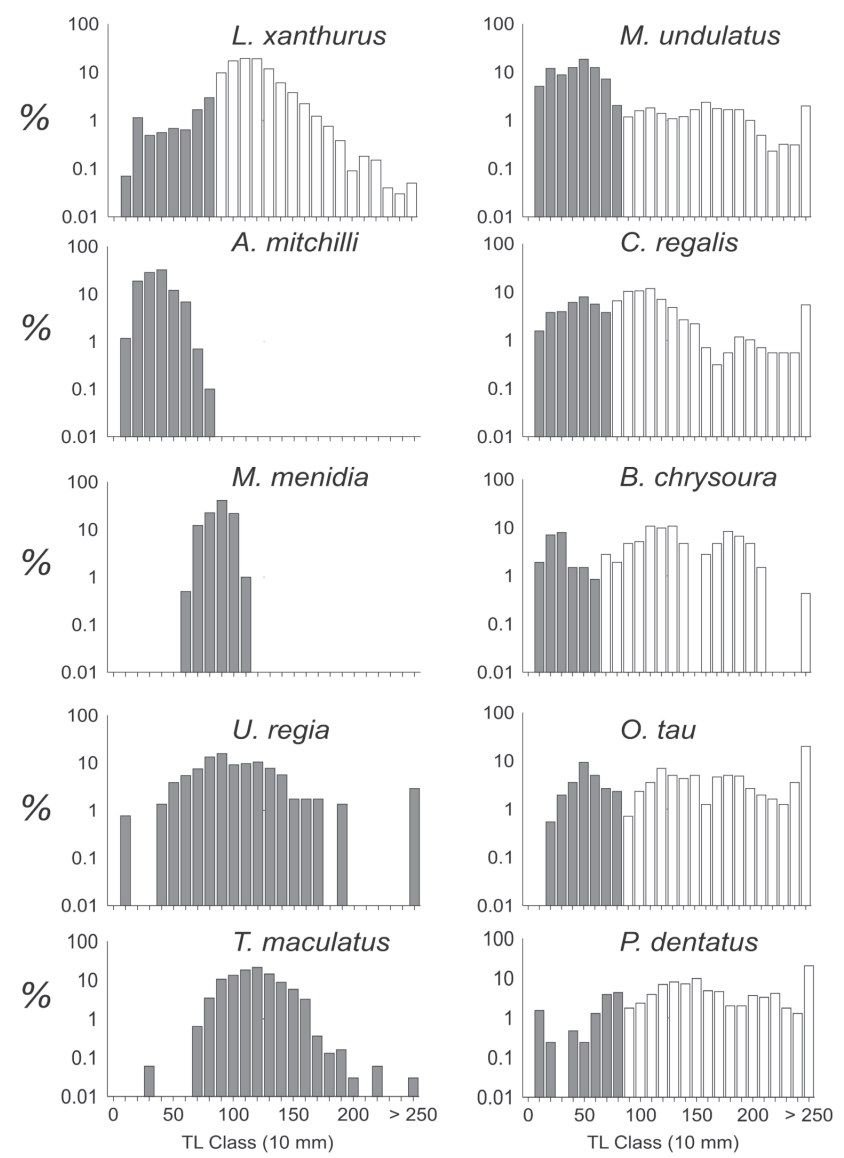

Figure 13. Percent size frequency distribution by $10 \mathrm{~mm}$ class length of 10 most abundant species at York River. Dark bars are Ecological Taxon I and open bars Ecological Taxon II. July 1973 to June 1974.

Cynoscion regalis ranked fifth in bottom trawl samples (Tab. III, Fig. 13) and was absent in collections made on January and February. Monthly and overall size frequency distributions suggested a tri-modal distribution, with at least two annual cohorts. Since larger individuals (> $200 \mathrm{~mm}$ ) of this species are generally not trawl-vulnerable, and occurred at a very low monthly abundance (CPUE < 0.3), we did not attempt to characterize larger individuals as separate SET. Based on monthly size distributions, two SET's were selected for future cluster analysis, CYNREG-I (<80 mm) and CYNREG-II (> $80 \mathrm{~mm})$.

The remaining 5 dominants species occurred in most month samples but at an average total CPUE of less than 1 (Tab. III, Fig. 13). Menidia menidia ranked seventh in bottom trawl samples but first in beach seine samples in the York River. This species occurred year-round in near shore areas, but only from November to March in bottom trawl samples, where most individuals were 80 to $100 \mathrm{~mm}$. Based on the limited size range represented in bottom trawl samples, the species was treated as a single SET for future cluster analysis.

Revista Brasileira de Zoologia 23 (1): 234-247, março 2006
Paralichthys dentatus, Opsanus tau, and Bairdiella chrysoura occurred mainly throughout the year in size ranges from 10 to $255 \mathrm{~mm}$ or larger and with several modal classes. Since larger individuals (generally $>70 \mathrm{~mm}$ ) of those species occurred monthly at very low abundance, and for each individual species, cluster analysis suggested no major temporal difference in occurrence among them, only characterized the first modal class of those species as SET-I and included all larger sizes in one category (SET-II). Also for Urophycis regia cluster analyses revealed no temporal or spatial differences between individuals smaller and larger than $90 \mathrm{~mm}$; therefore this species was treated as a single SET in subsequent cluster analysis.

Twenty four entities (12 SET's and 12 species) were selected for cluster analysis (Tab. III). Pooled data on entities abundance by month resulted in the following seasonal groups (Fig. 14): summer (June 1974 and July 1973), fall (August 1973 to October 1973), winter-1 (November 1973 to January 1974), winter-2 (February- March 1974) and spring (April-May 1974).

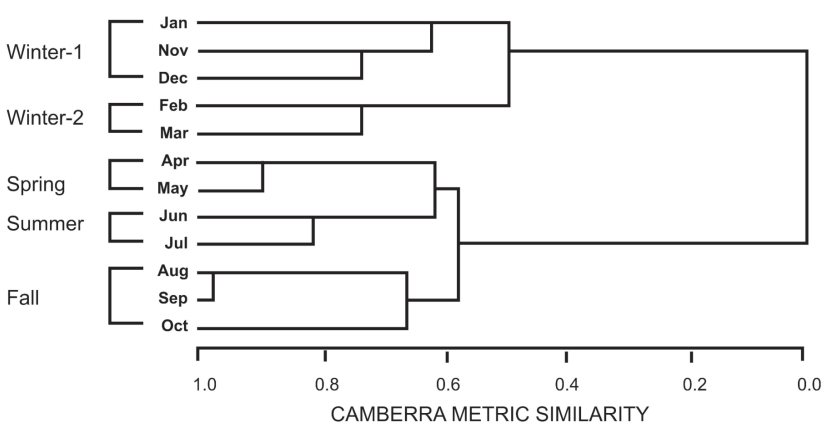

Figure 14. Dendogram of normal cluster analysis in the York River estuary.

Environmental data within these seasonal groups are summarized in figures 15 and 16 . Water temperature ranged between $15.0-28.0^{\circ} \mathrm{C}$ in fall, and $4.7-12.2^{\circ} \mathrm{C}$ in winter-2. Wide temperature ranges were observed in all seasonal groups $\left(7-13^{\circ} \mathrm{C}\right.$ of difference) but mean water temperatures were considerably lower in the two winter groups. Salinity variation was low in the portion of the river studied and ranged from 13.0 to 26.8 .

Inverse cluster analysis identified 10 groups of entities, ranging in content from one to five entities per group (Tab. IV). Groups A, B, and I were typified by numerically dominant entities (high to very high average individual CPUE), and together with groups C (low to moderate CPUE) occurred yearround. Entities of group D, although similar in abundance and occurrence to group C, were absent from the samples in February and March, suggesting winter emigration from the sampling area or gear avoidance (e.g. mud burrowing) for the majority of the entities of this group. Entities of group $\mathrm{E}$ were restricted in occurrence to winter months. Entities of group F were absent summer through fall. Entities of group $G$ were 
Table III. More frequent and abundant species of fish caught in the York River estuary from July 1973 to June 1974 sorted by average CPUE (mean capture per unit of effort). Species codes (SPCODE), numerical abundance (ABUN), CPUE, percent abundance (\%CPUE), and number of monthly frequency occurrence (FO).

\begin{tabular}{|c|c|c|c|c|c|c|}
\hline Species & \multicolumn{2}{|c|}{ Species code } & $A B \cup N$ & CPUE & \%CPUE & FO \\
\hline Anchoa mitchilli & ANCMIT & \# & 84240 & 178.89 & 75.95 & 12 \\
\hline Leiostomus xanthurus & LEIXAN & $\#$ & 14064 & 34.67 & 14.72 & 12 \\
\hline Micropogonias undulatus & MICUND & $\#$ & 3421 & 10.21 & 4.33 & 12 \\
\hline Trinectes maculatus & TRIMAC & $\#$ & 3060 & 5.89 & 2.50 & 12 \\
\hline Cynoscion regalis & CYNREG & $\#$ & 585 & 1.11 & 0.47 & 9 \\
\hline Paralichthys dentatus & PARDEN & $\#$ & 386 & 0.83 & 0.35 & 12 \\
\hline Menidia menidia & MENMEN & $\#$ & 182 & 0.75 & 0.32 & 5 \\
\hline Urophycis regia & UROREG & \# & 237 & 0.52 & 0.22 & 7 \\
\hline Opsanus tau & OPSTAU & \# & 247 & 0.48 & 0.20 & 11 \\
\hline Bairdiella chrysoura & BAICHR & \# & 211 & 0.40 & 0.17 & 9 \\
\hline Syngnathus fuscus & SYNFUS & \# & 86 & 0.17 & 0.07 & 8 \\
\hline Brevoortia tyrannus & BRETYR & \# & 75 & 0.15 & 0.06 & 5 \\
\hline Symphurus plagiusa & SYMPLA & \# & 61 & 0.13 & 0.06 & 7 \\
\hline Menticirrhus saxatilis & MENSAX & & 57 & 0.11 & 0.05 & 2 \\
\hline Alosa sapidissima & ALOSAP & $\#$ & 35 & 0.11 & 0.04 & 5 \\
\hline Morone americana & MORAME & $\#$ & 43 & 0.09 & 0.04 & 5 \\
\hline Chaetodipterus faber & CHAFAB & & 45 & 0.08 & 0.04 & 2 \\
\hline Prionotus carolinus & PRICAR & & 44 & 0.08 & 0.04 & 3 \\
\hline Alosa pseudoharengus & ALOPSE & \# & 25 & 0.07 & 0.03 & 5 \\
\hline Anchoa hepsetus & ANCHEP & & 35 & 0.07 & 0.03 & 2 \\
\hline Alosa aestivalis & ALOAES & & 28 & 0.06 & 0.03 & 3 \\
\hline Centropristis stiata & CENSTR & \# & 29 & 0.06 & 0.03 & 6 \\
\hline Peprilus triacanthus & PEPTRI & & 27 & 0.05 & 0.02 & 3 \\
\hline Synodus foetens & SYNFOE & & 26 & 0.05 & 0.02 & 3 \\
\hline Orthopristis chrysoptera & ORTCHR & & 23 & 0.04 & 0.02 & 3 \\
\hline Anguilla rostrata & ANGROS & & 22 & 0.04 & 0.02 & 3 \\
\hline Prionotus evolans & PRIEVO & & 14 & 0.04 & 0.02 & 3 \\
\hline Peprilus alepidotus & PEPALE & & 20 & 0.04 & 0.02 & 3 \\
\hline Hypsoblennius hentzi & HYPHEN & \# & 15 & 0.04 & 0.02 & 4 \\
\hline Menticirrhus americanus & MENAME & & 16 & 0.03 & 0.01 & 2 \\
\hline Gobiosoma bosci & GOBBOS & & 14 & 0.03 & 0.01 & 3 \\
\hline Syngnathus floridae & SYNFLO & & 15 & 0.03 & 0.01 & 2 \\
\hline Lagodon rhomboides & LAGRHO & & 13 & 0.02 & 0.01 & 2 \\
\hline Cynoscion nebulosus & CYNNEB & & 3 & 0.02 & 0.01 & 1 \\
\hline Apeltes quadracus & APEQUA & & 5 & 0.01 & 0.01 & 2 \\
\hline Tautoga onitis & TAUONI & & 6 & 0.01 & 0.01 & 3 \\
\hline Pomatomus saltatrix & POMSAL & & 4 & 0.01 & 0.01 & 1 \\
\hline
\end{tabular}

\# Denotes species used in cluster analysis.Tota:I 63 secies; 107,476 individuals; 12 months; 495 samples. 


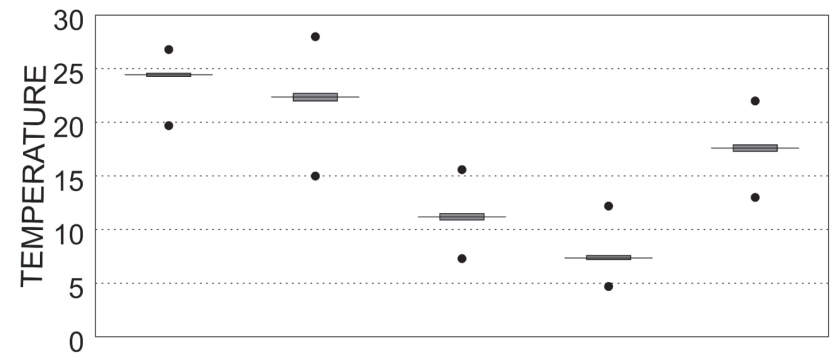

15

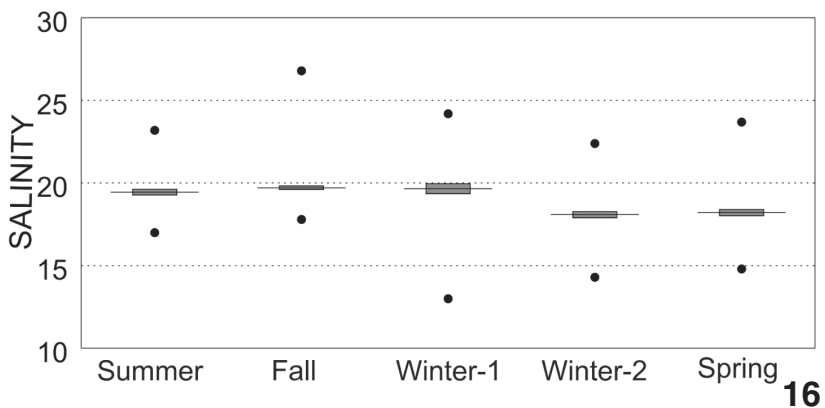

Figures 15-16. Salinity (15) and temperature (16) within seasonal groups in the York River estuary. Mean (horizontal line), standard error of the mean (Box), and range (Dots).

absent from winter-2 to spring months. Entities of group $\mathrm{H}$ were absent from spring samples. Juveniles of Paralichthys dentatus (PARDEN-1, Group J) were absent from winter-1 months and occurred at low abundance during the rest of the year.

\section{DISCUSSION}

The total number of species captured in most estuaries is moderate compared with nearby marine or freshwater systems, and Patos Lagoon and York River fish assemblages were numerically dominated by a few species, a characteristic that is also shared by other temperate and war-temperate estuaries (DEEGAN 1989, Vieira \& Musick 1993, Vieira \& Castello 1997, Potter \& HyNDES 1999). No dominant species were shared between both estuarine systems, but three dominant families and two genera were common to both data sets (Engraulididae - Anchoa, Sciaenidae - Micropogonias and Batrachoididae). When comparing the less abundant species, several were common to the Patos Lagoon and the York River (e.g., Menticirrhus americanus, Selene setapinnis, Selene vomer, Pomatomus saltatrix, Peprilus paru), and more than ten genera were common to both data sets.

Patos Lagoon fish assemblages have higher diversity than York River at any particular point in time, but the seasonal pattern of use of the estuary (i.e., nursery and feeding grounds) was similar between localities, and did not differ from other temperate or tropical estuaries. The total number of species (65 and 63, respectively) collected over a year of bottom trawling in Patos Lagoon and York River, was about the same. Sixty-five species represented $79 \%$ of all species reported from a three-year bottom trawl fish survey in Patos Lagoon estuary (Снао et al. 1982, 1985, Vieira \& Castello 1997). Sixty-three species represented $95 \%$ of those species taken by bottom trawl during a three year period in the York River (IlLowsky \& ColvocoResses 1975).

Within broad limits, the Patos Lagoon and York River structural assemblage patterns were correlated with temperature changes, although the intensity of seasonal changes differed between them. The major difference seems to occur in the winter months (June to August in Patos Lagoon, and November to March in the York River), where the cold season duration was longer in the York River than Patos Lagoon (5 vs 3 months, respectively), and the average monthly winter temperatures were consistently lower in the York River. The lowest winter temperatures in the York River were correlated with a pronounced seasonal species emigration from the estuary and the arrival of the boreal gadid Urophycis regia.

Several authors recommended the use of ecological guild classification scheme for further studies on comparison among geographically different estuarine fish assemblages (see Mathieson et al. 2000 and Thiel et al. 2003 for review), but those classification is reductive and agglomerative and the procedure of identified "size ecological taxa" SET (PoLIs 1984, GeLwick 1990) among abundant species is divisive and based on the axiom that the "species" category is not always appropriate as the smaller ecological entity. Since estuarine fishes often exhibit ontogenetic shifts in habitat requirements and/or preferences (Deegan 1989, Vieira \& Castello 1997) this procedure reduces the noise caused by lumping together large and small individuals of the same species, which have different temporal and spatial distributions and may not belong to a specific spatial ecological guild. Also the information gained by using SET treatment is important in the way to analyze and understand differences in temporal and spatial dynamics of fish assemblages. In order to do such numerical comparisons CPUE's by size classes, or SET's CPUE, has to be analyzed. Another advantage of the use of CPUE's by size classes is that the technique allow the growing in size and the reduction in numbers of one cohorts to be fallow in time and space (Whiteside \& НАTCH 1997).

Fish species in experimental bottom trawl collections of Patos Lagoon and the York River were primarily represented by post-larvae, young-of-the-year and sub-adults ranging in length between 10 and $250 \mathrm{~mm}$ or larger. In both localities the strongest modal class was $<80 \mathrm{~mm}$ TL. Around the cutoff size of 80 $100 \mathrm{~mm}$ we effectively separated SET's for 5 and 6 numerically dominant species in both systems. In addition another 5 abundant species were smaller than $100 \mathrm{~mm}$ TL. Exceptions to the low abundance of the $80-100 \mathrm{~mm}$ size range in the York River were: Adults of Menidia menidia, that occurred year-round in the near shore areas (Illowsky \& COLVOCORESSES 1975, WAGNER \& Austin 1999), but only in winter months in bottom trawl samples (but most individuals were 80 to $100 \mathrm{~mm} \mathrm{TL}$ ), Urophycis regia that also was only captured in cold months and Trinectes 
Table IV. Graphical characterization of CPUE variation of seasonal groups and species groups in the York River. Size range (mm).

\begin{tabular}{|c|c|c|c|c|c|c|c|}
\hline Groups & Species & Size range & SUM & FAL & WIN-1 & WIN-2 & SPR \\
\hline \multirow[t]{3}{*}{ A } & Anchoa mitchilli & $10-180$ & +++++ & +++++ & ++++ & +++++ & ++++ \\
\hline & Leiostomus xanthurus II & $90>250$ & ++++ & ++++ & ++++ & ++++ & ++++ \\
\hline & Micropogonias undulatus I & $10-70$ & ++ & +++ & ++++ & ++++ & +++ \\
\hline \multirow[t]{3}{*}{ B } & Trinectes maculatus & $30-240$ & +++ & +++ & ++ & +++ & +++ \\
\hline & Micropogonias undulatus II & $80>250$ & +++ & +++ & +++ & +++ & ++ \\
\hline & Paralichthys dentatus II & $90>250$ & ++ & ++ & +++ & +++ & ++ \\
\hline \multirow[t]{2}{*}{$\mathrm{C}$} & Symphurus plagiusa & $30-150$ & ++ & +++ & ++ & +++ & ++ \\
\hline & Opsanus tau I & $20-80$ & ++ & ++ & ++ & +++ & ++ \\
\hline \multirow[t]{5}{*}{$\mathrm{D}$} & Opsanus tau II & $90>250$ & ++ & ++ & ++ & & ++ \\
\hline & Cynoscion regalis II & $80>250$ & ++ & +++ & ++ & & ++ \\
\hline & Bairdiella chrysoura II & $70-240$ & ++ & +++ & ++ & & ++ \\
\hline & Syngnathus fuscus & $60-210$ & +++ & +++ & ++ & & ++ \\
\hline & Centropristis stiata & $20>250$ & ++ & ++ & ++ & & ++ \\
\hline \multirow[t]{3}{*}{$\mathrm{E}$} & Alosa pseudoharengus & $10-110$ & & & +++ & ++ & \\
\hline & Alosa sapidissima & $10-120$ & & & +++ & ++ & \\
\hline & Menidia menidia & $60-110$ & & & +++ & ++ & \\
\hline \multirow[t]{2}{*}{$\mathrm{F}$} & Brevoortia tyrannus & $20-200$ & & & ++ & ++ & +++ \\
\hline & Urophycis regia & $10>250$ & & & ++ & +++ & +++ \\
\hline \multirow[t]{2}{*}{ G } & Cynoscion regalis I & $10-70$ & & +++ & + & & \\
\hline & Bairdiella chrysoura I & $10-60$ & ++ & ++ & ++ & & \\
\hline \multirow[t]{2}{*}{$\mathrm{H}$} & Hypsoblennius hentzi & $20-80$ & & ++ & ++ & & \\
\hline & Morone americana & $100>250$ & +++ & & +++ & ++ & \\
\hline 1 & Leiostomus xanthurus I & $10-80$ & +++ & ++ & ++ & ++ & +++ \\
\hline J & Paralichthys dentatus I & $10-80$ & ++ & + & & + & ++ \\
\hline
\end{tabular}

Absent (empty), very low (+<0.01); low (++>0.01); moderate $(+++>0.1)$; high (++++> 1.0); very high $(+++++>10$.

maculatus, a year-round estuarine-resident, with most individual between 90 and $160 \mathrm{~mm}$ TL but protected by mud burrowing. Only one exception occurred at Patos Lagoon, three species of sea catfish of the genus Genidens, in which the majority of the 0+ individuals were between 60 and $90 \mathrm{~mm}$ TL (VIEIRA \& CASTELlo 1997), and which occurred year round but protected by strong dorsal and pectoral spines. In warm months, when predation by large fish may be strongest (Buckel et al. 1999b, Hartman 2000), the abundance of fish between 80 and $100 \mathrm{~mm}$ TL was lower in demersal fish assemblages in both systems. Only the sea catfish Genidens spp (Patos Lagoon), and the flounder Trinectes maculatus (York River), peak in abundance at this size class because they are protected from predation.

In this study many similarities (ecological analogies) were observed between estuarine bottom trawl fish assemblages in two geographically isolated systems within warm-temperate latitudes of the western Atlantic. We document deep water use of both estuaries for post-larvae and young-of-the-year recruitment, nursery, shelter and feeding grounds, with is also shared by other western Atlantic temperate estuaries (SHAw et al. 1988,
Vieira \& Castello 1997) and elsewhere in the world (Potter \& Hyndes 1999, Mathieson et al. 2000). Another important information that complements this observation is that around 80 and $100 \mathrm{~mm}$ TL many species in both systems left the area or moved to shallow water to avoid predation. Future works have to be done in order to investigate why the 80 to $100 \mathrm{~mm} \mathrm{TL}$ fish were absent from bottom trawl waters (this work) but occurs frequently as food items of estuarine piscivorous fish such as bluefish Pomatomus saltatrix and striped bass Morone saxatilis (Buckel et al. 1999a, b, Manderson et al. 1999, Hartman 2000) and also wading birds (FÁvero et al. 2001).

The results presented hear was consistent with the hypothesis of a trade-off between the feeding benefit and predation risk, and our findings provide empirical support for the hypothesis that the size around 80 and $100 \mathrm{~mm}$ TL are an important breakpoint between to be small, live in the water column and feed on zooplancton food chain or to be large enough to migrate to the bottom, explore estuarine abundant benthos resources, and run from predation (Power 1987 in Helfman et al. 1997).

Revista Brasileira de Zoologia 23 (1): 234-247, março 2006 


\section{ACKNOWLEDGMENTS}

This work was made possible and supported by CAPES (Coordenadoria de Aperfeiçoamento de Pessoal de Nível Superior), Brazil. Special thanks to Dr. J. Musick, J. Colvocoresses, L. Chao, L. Pereira and M. Bemvenuti for providing part of the data set on which we based this work, and to several colleges for reviewing the manuscript.

\section{REFERENCES}

Araújo, F.G. \& M.C. Azevedo. 2001. Assemblages of SoutheastSouth Brazilian Coastal Systems based on the distribution of fishes. Estuarine, Coastal and Shelf Science, London, 52 (6): 729-738.

BLONDEL, J. 1991. Assessing convergence at the community-wide level. Trends in Ecology \& Evolution, Amsterdam, 6 (9): 271-272.

Buckel, J.A.; D.O. Conover; N.D. Steinberg \& K.A. McKown. 1999a. Impact of age-0 bluefish (Pomatomus saltatrix) predation on age-0 fishes in the Hudson River estuary: evidence for density-dependent loss of juvenile striped bass (Morone saxatilis). Canadian Journal of Fisheries and Aquatic Sciences, Ottawa, 56 (2): 275-287.

BuCKEL, J.A.; M.J. FogarTy \& D.O. CONOvER. 1999b. Foraging habits of bluefish, Pomatomus saltatrix, on the U.S. east coast continental shelf. Fishery Bulletin, Washington, 97 (4): 758775.

Chao, L.N.; L.E. Pereira; J.P. Vieira; M.A. Bemvenuti \& L.P.R. CuNHA. 1982. Relação preliminar dos peixes estuarinos e marinhos da Lagoa dos Patos e região costeira adjacente, Rio Grande do Sul, Brasil. Atlântica, Rio Grande, 5 (1): 67-75.

Chao, L.N.; L.E. Pereira \& J.P. Vieira. 1985. Estuarine fish community of the Patos Lagoon, Brazil: a baseline study, p. 429-450. In: A. Yanez-Arancibia (Ed.). Fish community ecology in estuaries and coastal lagoons: towards an ecosystem integration. Mexico, UNAM Press, 654p.

Deegan, L.A. 1989. Nekton, the Free-Swimming Consumers, p. 377-437. In: J.W. DaY; C.A.S. Hall; W.M. KemP \& A. YaneZArancibia (Eds). Estuarine Ecology. New York, Wiley-Interscience, $558 \mathrm{p}$.

EKMAN, S. 1953. Zoogeography of the sea. London, Sidgwick \& Jackson, XIV+417p.

Fávero, M.; M. Jelicich-Rocio; M.P. Silva; M.S. Bo \& C.M. Garcia. 2001. Food and feeding biology of the Black Skimmer in Argentina: evidence supporting offshore feeding in nonbreeding areas. Waterbirds, De Leon Springs, 24 (3): 413418.

Feinsinger, P. 1990. North-South temperate ecosystems: meeting reviews. Bulletin of the Ecological Society of America, Tempe, 71 (3): 200-202.

Garcia, A.M.; J.P. Vieira \& K.O. Winemiller. 2001. Dynamics of the shallow-water fish assemblage of the Patos Lagoon estuary (Brazil) during cold and warm ENSO episodes.
Journal of Fish Biology, London, 59 (5): 1218-1238.

GeLwick, F.P. 1990. Longitudinal and temporal composition of riffle and pool fish assemblages in a northeastern Oklahoma Ozark stream. Copeia, Lawrence, 4: 1072-1082.

Hartman, K.J. 2000. The influence of size on striped bass foraging. Marine Ecology Progress Series, Amelinghausen, 194: 263-268.

Harvey, P.H.; R.K. Colwell; J.W. Silvertown \& R.M. May. 1983. Null models in ecology. Annual Review Of Ecology and Systematics, Palo Alto, 14: 189-211.

Helfamn, G.S.; B.B. Collette \& D.E. Facey. 1997. The diversity of fishes. Malden, Blackwell Science, 528p.

Illowsky, J.E. \& J. Colvocoresses. 1975. Fish and major decapods. Special Scientific Report, Virginia Institute of Marine Science, Gloucester Point, 76: 1-209.

Manderson, J.P.; B.A. Phelan; A.J. Bejda; LL. Stehlik \& A.W. Stoner. 1999. Predation by striped searobin (Prionotus evolans, Triglidae) on young-of-the-year winter flounder (Pseudopleuronectes americanus, Walbaum): examining prey size selection and prey choice using field observations and laboratory experiments. Journal of Experimental Marine Biology and Ecology, Amsterdam, 242 (2): 211-231.

Mathieson, S.; A. Cattrijsse; M.J. Costa; P. Drake; M. Elliott; J. Gradner \& J. Marchand. 2000. Fish assemblages of european tidal marshes: a comparison based on species, families and functional guilds. Marine Ecology Progress Series, Amelinghausen, 204: 225-242.

Murdy, E.D.; R.S. Birdsong \& J.A. Musick. 1997. Fishes of Chesapeake Bay. Washington, Smithsonian Institution Press, $324 p$.

Petrik, R. \& P. Levin. 2000. Estimating relative abudance of seagrass fishes: a quantitative comparison of three methods. Environmental Biology of Fishes, Dordrecht, 58 (4): 461466.

Polis, G.A. 1984. Age structure components of niche width and intraspecific resource partitioning: can age function as ecological species? American Naturalistic, Chicago, 123 (4): 541-564.

PotTer, I.C. \& G.A. Hyndes. 1999. Characteristics of the ichthyofaunas of southwestern australian estuaries, including comparisons with holarctic estuaries elsewhere in temperate Australia: a review. Australian Journal of Ecology, Carlton, 24 (4): 395-421.

SHaW, R.F.; B.D. Rogers; J.H. CoWAN JR. \& W.H. Herke. 1988. Oceanestuary coupling of ichthyoplankton and nekton in the Northern Gulf of Mexico. American Fisheries Society Symposium, Bethesda, 3: 77-89.

Stokesbury, K.D.E.; J.B. Bichy \& S.W. Ross. 1999. Selectivity and efficiency of two otter trawls used to assess estuarine fish and macroinvertebrate populations in North Carolina. Estuaries, Columbia, 22 (4): 882-888.

Thiel, R.; H. Cabral \& M.J. Costa. 2003. Composition, temporal changes and ecological guild classification of the ichthyo- 
faunas of large european estuaries: a composition between the Tagus (Portugal) and the Elbe (Germany). Journal of Applied Ichthyology, Berlin, 19: 330-342.

VIEIRA, J.P. \& J.A. Muscik. 1993. Latidudinal patterns in diversity of fishes in warm temperate and tropical estuarine waters of the western Atlantic. Atlântica, Rio Grande, 15 (1): 112 133.

Vieira, J.P. \& J.A. Musick. 1994. Fish faunal composition in warmtemperate and tropical estuaries of the Western Atlantic. Atlântica, Rio Grande, 16 (1): 31-53.

Vieira, J.P. \& J.P. Castello. 1997. Fish fauna, p. 56-61. In: U. Seelinger; C. Odebrecht \& J.P. Castello (Eds). Ecology of subtropical convergence regions: the coast and sea in the warm-temperate Southwestern Atlantic. New York, Springer-Verlag, 308p.

WAGNer, C.M. \& H.M. Austin. 1999. Correspondence between environmental gradients and summer littoral fish assemblages in low salinity reaches of the Chesapeake Bay, USA. Marine Ecology Progress Series, Amelinghausen, 177: 197-212.

Westoby, M. 1988. Comparing australian ecosystems to those elsewhere: what is the significance of evolutionary history? BioScience, Washington, 38 (8): 549-556.

Whiteside, M. \& J.T. Hatch. 1997. Quantitative sampling techniques for age-0 fish from diverse lake habitats Arch. Hydrobiol. Spec. Issues advanc. Advances In Limnology, Stuttgart, 49: 99-116.

Received in 31.V.2005; accepted in 24.II.2006. 